\title{
Informed Societies: Why Information Literacy Matters for Citizenship, Participation and Democracy
}

Goldstein, Stéphane, ed. 2019. Informed Societies: Why Information Literacy Matters for Citizenship, Participation and Democracy. London: Facet Publishing. xxx, 235 pp. ISBN: 9781783303922.

We live in a time of information explosion. What we can learn is right at our fingertips, but often what we should learn is less clear. Misinformation has become a marketplace, often peddled by those attempting to sway belief. While such misinformation is often political in nature, it does not come from one side of the spectrum. Bias has always been apparent in politics, but outright misinformation has become a ubiquitous method of influencing hearts and minds. In light of this, what does it mean to be an informed citizen? Furthermore, how important is an informed citizenry, free of misinformed notions, to the pursuit of democracy? Finally, how do we, as information professionals, play a role in informing citizens, not only in providing the information, but also the tools to evaluate information in order to see through the bias, disinformation, and "fake news"?

This edited volume seeks to answer all of the questions above. The editor does so by looking beyond traditional information literacy, collecting essays from an international cohort of information professionals, including librarians, psychologists, political theorists and activists, cognitive scientists, and more. Each essay seeks, in its own right, to look into the importance of critical information literacy from the lens of each specialization, focusing on its importance in the overall democratic process on both micro and macro levels. While not explicit, the editor frames these essays as a narrative focusing on four major themes, with two to four essays on each: an examination of political theory, psychology and the politics of information literacy, international and national policy, and fostering political engagement. While differing greatly in both breadth and depth, every essay works from similar and fairly explicit premises. These are that critical media and digital literacy is a basic human right, with universal access to information as a social justice issue, that a cooperative global effort is needed to address this, and that this critical literacy is necessary for informed civil engagement both political and social. This understanding, therefore, places critical information literacy distinctly in the realm of the political.

The first two sections look at political theories of democracy and the power, influence, and privilege that information and, moreover, the control of misinformation, has in removing informed citizenry from participation. As Gianfranco Polizzi states in his essay, what we are seeing on an ever-increasing scale is "misinformation undermining citizen's engagement in civic and political life" (1). These also look at how media can influence perception through misinformation that, even when finally corrected, can have a lasting effect on people's understanding of the original, biased information. Stephan Lewandowsky also looks into philosophical theories of communication and the ethical implications thereof, focusing heavily on the theories of Habermas and Bakhtin.

The second theme, with essays from a psychologist and a cognitive scientist, looks at social identity, belief, and the long-term effects of misinformation on cognition. While these essays do not address the role of the librarian, let alone the theological librarian, they are of particular interest in their direct implications for belief and ethical behavior. Drawing heavily on the theory of intellectual empathy of Maureen Linker, Andrea Baer argues that, in an increasingly diverse and divided 
world, it is necessary to be empathetic towards those of differing, views, beliefs, and opinions in order to have productive dialog that allows critical thinking to break through cognitive bias based in belief. Lewandowsky, in his second essay in the volume, discusses an increasing disregard for truth in both politics and the public sphere in general, looking at the long-term consequences that misinformation can have on understanding and belief. He argues that this creates a level of cognitive dissonance that seeks to deny reality. Finally, he then applies this to building information systems that are better capable of stopping the spread of misinformation.

Chapters five through seven look at critical information literacy on a larger scale, focusing on national and international policy-making. Lau and Grizzle focus specifically on the intersection of media literacy and information literacy, considering UNESCO standards. John Crawford looks into initiatives in Western countries, primarily the UK, while the following essay by Raju, Johnson, and Majebe tackle the intersection of information literacy, democracy, and ubuntu philosophy in South African politics. While all three of these essays are excellent works in relating critical information literacy and informed citizenship, examples of practical application fall heavily on public and school libraries, when libraries are mentioned at all. This section, therefore, would assist a reader with philosophical understandings as well as a greater appreciation of the needs on a global scale, but applicability to academic librarianship is limited. That beings said, those who teach intersections of theology and global human rights might find these essays of particular interest.

The final section includes four essays that look at direct, practical applications for engaging users in civic participation through more critical understandings of information. The advantage of this section is certainly its applicability and real-world examples on a micro/community level. The first looks at building discernment amongst young people when approaching information. Looking at secondary school and college-age students in the UK, this essay seeks to apply active learning in the teaching of discernment. This, more than the other essays in the section, has the greatest application to theological librarianship, particularly at the level of higher education, as it looks at a larger portion of the population group worked with and that it is possible to intersect the theological concept of the gift of discernment with the application of critical thinking in everyday life. The final two essays look at the importance of information literacy with refugee populations and the aging, respectively. While both focus heavily on practical applications more akin to public library work, these two can be understood on a broader level as a need for critical information literacy in light on the change and progression of societal norms, social progress, and the need to understand these in civic engagement.

Considered as a whole, this collection has many strengths. Its scope is broad enough to consider significant philosophical and psychological implications while still creating space for looking at real-world issues applied to both larger societies and individual populations. The practical essays cover both public and academic libraries, as well as look at several population groups. It consistently leans into its stated goal of establishing critical literacy as a human right, essential for civic engagement, and it does so without moving too heavily into either the right or the left of the political spectrum. The comprehensive nature of the text is undeniable. Looking for weaknesses in the text as a whole, there is not much to say. One issue is that the most of the essays stand quite independent from one another; I can recall only a single instance where one essay makes explicit use of an essay that came previously in the book. As such, one will find that reading through the text requires going over many concepts and applications repeatedly, with the language sounding similar throughout. 
This somewhat repetitive nature does not lend itself to maintaining a thorough read but to a scan through larger portions of each essay to get to the heart of the authors' discussions.

To conclude, this collection, while quite dense, is packed with an incredible amount of information linking the work of librarians in critical literacy and the universal need to apply this teaching into everyday life to make us, and our students, more informed and therefore more able to think critically in political and social engagement. Regardless of the level of teaching one offers or the theological and/or denominational offerings of one's institutions, Informed Societies is an important tool in our information arsenal, and the volume can be a useful part of library collections both personal and institutional.

Alexis Nicole Weiss

Reference and Instruction Librarian for Theology Loyola Marymount University Los Angeles, CA 